\title{
FRAMEWORK PROPOSITION AND TECHNICAL GUIDELINES FOR MANUFACTURERS OF CUSTOM MADE TOOLS, MACHINERY AND SPECIAL EQUIPMENT
}

\author{
Matic Tepěs, Peter Krajnik, Janez Kopač
}

Original scientific paper

This paper overviews the state-of-the-art in modern forms of organization, collaboration and flexibility, trends and forecasts of the automotive industry as a representative buyer of tools, machines and special equipment, as well as life cycle management, sustainability and possibility for added value creation in these industry sectors. Based on this, a framework called "smart tool, machine, and special equipment" is proposed. A part of the research done on Slovene manufacturers is presented, where the technological indicators important in the implementation of the proposed framework are identified and ranked regarding to their importance. Additional suggestions by the manufacturers are also provided, as well as critical analysis and discussion of the findings.

Keywords: custom tools; flexibility; life cycle management; machines; smart; special equipment; value chain management; virtual organization

Prijedlog načela i tehničke smjernice za proizvođače alata po mjeri, strojeva i specijalne opreme

Izvorni znanstveni članak

U radu se daje pregled najnovijih dostignuća u modernim oblicima organizacije, suradnje i fleksibilnosti, trendovima i predviđanjima u automobilskoj industriji kao reprezentativnom kupcu alata, strojeva i specijalne opreme, kao i upravljanje vijekom trajanja, održivosti i mogućnosti stvaranja nove vrijednosti u tim industrijskim sektorima. Na temelju toga predlaže se okvirno načelo nazvano "pametni alat, stroj i specijalna oprema". Daje se dio istraživanja provedenog na slovenskim proizvođačima kod kojih su prepoznati tehnološki indikatori važni za implementaciju predloženog načela, te su rangirani u skladu s njihovom važnosti. Daju se i dodatne primjedbe koje su stavili proizvođači, te kritička analiza i rasprava rezultata.

Ključne riječi: alati po mjeri; fleksibilnost; pametan; strojevi; specijalna oprema; upravljanje lancem vrijednosti; upravljanje vijekom trajanja; virtualna organizacija

\section{Introduction}

The aim of this paper is to lay the foundation required for the development of a new conceptual framework for a tool making factory of the future, which can be used by companies to evaluate their value chain in order to improve market competitiveness. The smart (ICTenabled) factory concept focuses on integrated organizational and technological management, which includes organizational trends, industrial drivers, life cycle management and overall implementation of manufacturing operations, making the factory of the future more efficient and responsive to change. A product of a smart factory is hence intelligent, traceable and provides added value for the customer.

Different areas and industry trends, especially in the automotive industry, are taken into consideration, and new concepts are proposed. Important technological information for implementation of the framework, gathered through survey research is also presented. The research targeted on Slovene producers of tools, i.e. custom made interchangeable tools and special equipment for machine tools. Tool and die making (including the tooling involved in plastic moulding) is an industry with a relatively high degree of added value and innovation. It is knowledge intensive, typically low-volume, order-based discrete manufacturing, requiring relatively small material expenditure. The research is carried-out among Slovene producers of tools, for which comparative analyses have shown to be similar to those of other European countries [1]. These producers are developing and manufacturing the following:

- Sheet metal tools and dies,

- Bulk metal forming dies,
- Injection moulding tools,

- Rubber processing tools,

- Mineral processing tools,

- Metal casting dies,

- Gravity casting dies,

- Production of specialized machines and equipment,

- Production of standardized parts for tool and equipment building,

- Production of high precision parts and

- Prototyping tools.

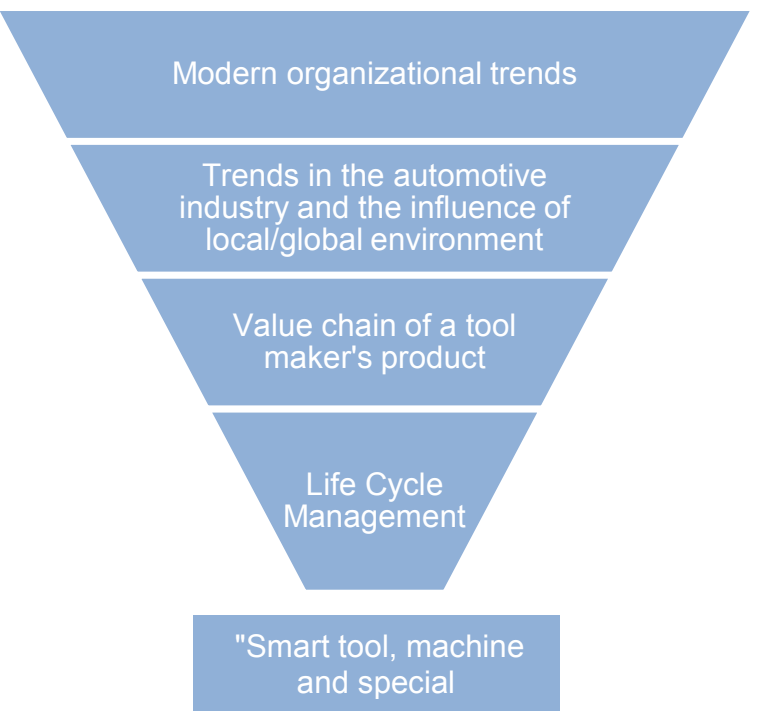

Figure 1 Backbone of the framework

The review of state of the art research was conducted in different areas, as depicted in Fig. 1, one of them are modern organizational trends (virtual breeding 
environments and virtual organizations, collaborative networks, business ecosystems, etc.). The second focus was on studies and forecasts for the future of the automotive industry, which was selected as a representative buyer - a high tech and a demanding customer of the European tool maker. The value chain of the representative product was analyzed, and then Life Cycle Management was reviewed. Some of the key findings, as well as the framework of "smart tool, machine and special equipment", that builds on these findings are presented in this paper.

\section{Manufacturing operations, value chain management, and technology}

This section reviews state-of-the-art in the changing world of manufacturing and global networks. Namely, new forms of organization, collaboration and flexibility, as well as new value chain management and manufacturing technologies for making smart tools, which create value.

\subsection{Manufacturing business environment and automotive industry as a representative buyer}

In a global business environment, small and mediumsized enterprises (SMEs) in countries with high costs of manufacturing compete with companies in regions where the cost of labour, capital and material is significantly lower. Nevertheless, the rising labour costs in developing countries are affecting the structure of global supply chains and in some cases a number of global companies are repatriating their manufacturing capabilities. Therefore, they must seek innovative solutions and keep in touch with the newest development and technology edge, in order to keep their competitive advantage. There is a general consensus in the EU that a new approach to manufacturing is required, one that is innovative, with a high added value and based on knowledge and capital, instead of land, labour and capital [2]. A good example of this is a new German research initiative - Industry 4.0 that foresees factories of the future characterized by the individualization of products, integration of customers and business partners in business and value-added processes and the linking of production and high-quality services [3].

A comparative study of the tool making customer base shows that some of the most demanding customers come from the automotive industry [1]. The representative buyer development trends of the Slovene tool makers are therefore those of the automotive industry. If we analyze the parts of a modern vehicle, manufactured by specialised tools and equipment, we can find out that the making of one vehicle requires the use of more than one thousand different tools [1].

The experts at Roland Berger Strategy Consultants in cooperation with other leading companies made an extensive study, in which they included more than 60 leading companies from the automotive industry worldwide. Their conclusions predict a dynamic turn of events in the automotive industry, encompassing change in technology, change in organization, and change in business models [4]. Five so-called megatrends, that will have a significant influence on the automotive industry in the years until 2025, were identified in the same study: geopolitical changes, demographic changes, sustainable development, evolution of mobility and technological changes. The smart tool, machine and special equipment manufacturers should align their vision and especially their strategy according to the future development of the environment, in which they will operate.

Original equipment manufacturers (OEM) will put pressure on their suppliers, such as tool makers and specialized equipment manufacturers, to more actively invest in research, production optimization, as well as management and tracking of information. Certain production development issues will be more actively delegated down to supply chain partners, as a part of an OEM strategy to maintain or enhance their business profitability. The OEMs will shift their focus to the added value provided by the suppliers in the realization process of the respective module of producing their end product the vehicle [1].The suppliers, on the other hand, are in the frontline for continuously improving productivity at reduced capital intensity. They need to innovate, develop and implement new business plans, engage in research (e.g. manufacturing cost and supply chain optimization), sales and services as well.

\subsection{New forms of organization, collaboration and flexibility in manufacturing related operations}

Future projections show a higher occurrence of open development platforms in the industry as well as across different industries and the products themselves are going to have a higher degree of complexity and adaptability [4]. One of the more important factors for doing business in the automotive industry is going to be flexibility. The next 15 years $(2010 \div 2025)$ are predicted to bring one of the biggest structural changes in the automotive industry to date. The players could use these changes to their benefit, if they are able to produce a high degree of flexibility [4]. Flexibility will be seen in different areas:

- flexible ownership models for products or services,

- flexible work time for employees,

- flexible organizational structure that allows smooth entrance and exit from the project oriented partnership.

The OEM can achieve a higher degree of flexibility or so called agility in the form of a virtual organization [5]. Other measures in place for agility are continuous improvement processes, review of key risks and evolving organizational capabilities. Moreover, the automotive industry is characterized by a high level of capital investment, with OEMs and tier-1 suppliers reinvesting a large percent of their annual revenues. In such business environment for SMEs to succeed, they must be knowledge based, innovative and collaborative. However, research consumes a lot of time and resources, which are limited in particular SMEs. Moreover, joint research can be quicker and more insightful than solo efforts. Insights gained in such collaboration can be, for example, used to optimize product performance and refine product portfolios. Setting up technological networks, that enable inter-organizational cooperation is therefore beneficial 
and arguably critical. Improved, network-enabled capacity can better tackle supply bottlenecks and drive growth without much capital investment. This operational flexibility brings the ability for ramping production in different areas of a network.

Networks are hence virtual capacities in the form of research, machines, as well as knowledge in the form of data/information and in the form of experts, which is available for the completion of goals and projects, but is not necessarily a part of a single organization. The network here acts as a base, a sort of virtual breeding environment that enables quick and efficient formation of virtual organizations if needed [6]. Examples are networks for: (1) European Product Development
Enterprises in Manufacturing and Innovation [7]; (2) Tool-Making Cluster of Slovenia [8]; International Virtual Laboratory for Enterprise Interoperability [9], and similar. A virtual organization is more than just outsourcing, and does not represent a simple division of the "pie into more pieces", it acts synergistically through cooperation from development to production and creates added value for all stakeholders. In such an environment the emphasis is on a different approach that involves information exchange and cooperation with the customers, the suppliers and ideally even between (former) competitors [10]. For example, benefit of suppliers is more stable business; they become more costcompetitive and improve their key competencies.
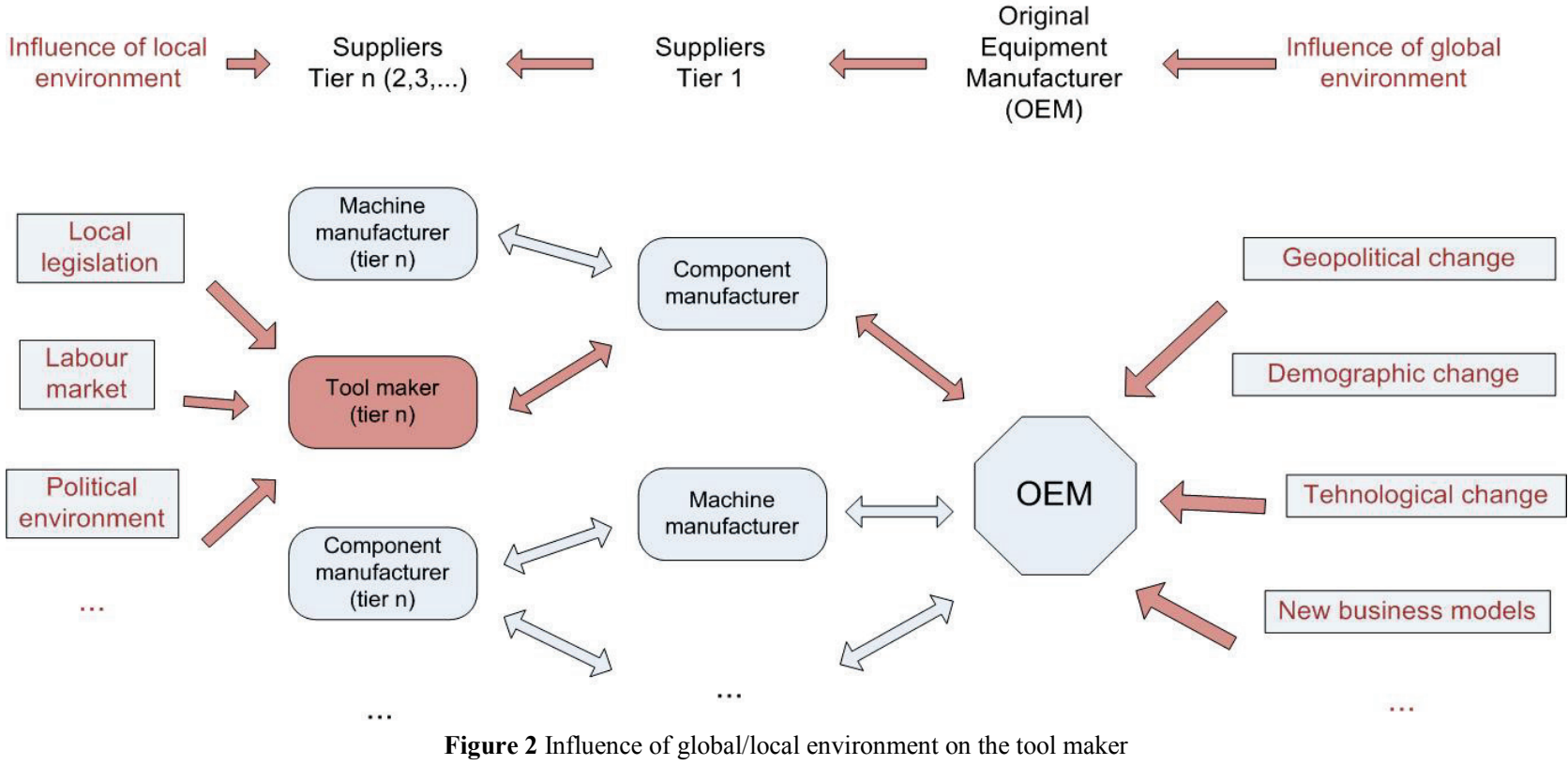

Today, different forms of organizational collaboration are already present, such as joint ventures, strategic partnership and outsourcing. Collaboration is defined as the joint development of capabilities for both the customer and supplier for the purposes of reduced cost, process improvements and innovation in products or services. This is only the beginning, which indicates the future of successful organizations that will be based on spontaneous collaboration and the creation of networks [11]. When discussing modern organizational structures, we are talking about networks that lead to the formation of virtual organizations, virtual factories or clusters. The network itself is viewed as an inactive form of cooperation, whereas the virtual organization represents its active form [5].

Based on the literature review of virtual organizations in the field of manufacturing, we are able to determine the basic characteristics of this organizational form, which are $[6,12 \div 17]$ :

- Provision of key competencies of each network member,

- increased organizational and manufacturing agility,

- cooperation backed up by appropriate ICT infrastructure and

- cultivation of trust within the network.
On the level of a specific project (project engineering), the virtual organization has to be able to fully exploit the possibilities of modern ICT for their needs of cooperation, communication and coordination [15]. A virtual organization has to be supported by modern ICT and fast communication networks, databases and special standards for the exchange of working documentation, such as 3D-models. Moreover, driven by the Internet, the real and virtual worlds are growing closer and closer together to form the Internet of Things [3]. This digitalization of manufacturing will likely increase the effectiveness of business processes and infrastructures (driven by innovative business models), supporting manufacturing operations that strengthen the competitive position of the industry.

Cooperation in technology networks and virtual organizations requires the use of open systems and robust industry standards, such as: standardized machine interface, standards of cooperation and product data management, standards of communication in the supply chain, standards for data exchange between different organizations FIS systems (Factory Information System), and standards for the exchange of data between ERP (Enterprise Resource Planning), PLM (Product Lifecycle Management), MES (Manufacturing Execution System) and PLC (Programmable Logic Controller) [11, 18]. Last 
but not least, implementations of networked (distributed) manufacturing are many - for example conceptual framework for collaborative product design and related manufacturing system development, operations and maintenance [19], or business-to-manufacturing network consisting of autonomous work system [20].

\subsection{Value chain management}

Life cycle engineering (LCE) is a key concept for promoting environmentally sustainable practices among manufacturing value chain [21]. The production of environmentally friendly products, with clear quantified targets for reuse, recycling and recovery is already driven by legislation (e.g. EU's Directive 2000/53/EC on end-of life vehicles), that is especially present in the field of the automotive industry. International standards for environmental regulations are mostly based on a holistic view of the product life cycle [22]. In addition to the aforementioned political decisions and regulations, there is also a potential for added value creation in the concept of product life cycle management. We can argue that an overview of a product life cycle provides new opportunities for lowering expenses and increasing productivity during the phase of product exploitation. In collaborating, the buyer/user receives expert support from the producer and the producer receives quality feedback and payment for after sales service. Therefore, the producers offer more than just a tool or technical product, they offer a fulfilment of a production need of the buyer, based on their own knowledge and expertise. In such a business model, the change of ownership is not necessary, the physical product can remain the property of the producer, if such a scenario is reasonable. The goal is an economical product life cycle with an efficient use of resources, such as materials, knowledge and work capacity [22].

The optimization of the entire product life cycle was first recognized in the ISO 14040-14043, the so called life cycle assessment (LCA). A major hurdle in the implementation of LCE is the lack of a systematic and strategic method to design or plan an entire product life cycle. All this has led to rediscovering of the "complete life cycles of products". There is a question in the industry: "How to create added value throughout the entire life cycle of a given product?". In this context, the product life cycle management (PLM) represents business activity of managing products and services, all the way across their life cycles [22], with the objectives of: (1) maximizing the value of the product portfolio, (2) increasing product revenues and (3) increasing the possibility of managing product complexity within same project time. Another progress beyond the state-of-the-art is a resource-conservative remanufacturing paradigm, in which products are designed for multiple life cycles with predefined life cycle management strategies, adding value to both, forward and reverse value chain [23]. The producers must hence take a greater responsibility for the use and the consequences of the use of their products. However, the general belief thus far, at least in most Slovene producers in the field, has been that the costbenefit ratio of after sale services is not favourable [24]. Smart manufacture of tools, nonetheless, should combine the flexibility and "custom-made", which can be achieved by modularization and mass customization, i.e. through design, in particular during the conceptual design and preliminary development stages [25]. The detailed description of value chain management for mass customization of tool-making, such as customer and OEM demands, modularity, change and variant management is beyond the scope of this paper. The opportunities and challenges of mass customization for manufacturing and services can be found in reference [26].

Sustainable production has a central role in the manufacturing value chain since it drives the future of manufacturing as well as operational and supply chain strategies. Sustainable production has implications on different manufacturing scale levels: from a unit (discrete) process (e.g.) machining focus [27,28], the manufacturing system (e.g. machine) [29], to supply chain levels [23, 30, 31].

In line with sustainable manufacturing, there is an ever growing general social ecological awareness and many organizations are now publicly striving for environmental protection and corporate social responsibility (CSR), depending on the size of corporation, operational conditions, market conditions, industrial life cycle, etc. [32].

\subsection{Manufacturing technologies and industrial operations}

This section outlines the role of manufacturing technologies, in particular, operations used in the smart tool, machine, and special equipment manufacture. The manufacturing of dies and moulds represents a major operation in the tool-making production chain, because nearly all mass produced discrete parts are formed using manufacturing technologies that employ dies and moulds [33]. The underlying forming technologies consist of sheet metal forming [34], injection moulding and die casting. Each individual technology is characterized by a multitude of factors (e.g. defects in key segments, vibrations, etc.) affecting its operational performance. The case study presented in section 4 will provide valuable information about the parameters that are the most critical in industrial operations.

In parallel, the tool makers are constantly advancing and implementing the latest technology in: part and process design; tool material [35]; rapid prototyping and tooling; novel machining of forming tools, e.g.by grinding [36]; optimized tool path generation for high speed cutting and hard machining [37]; machine and tools [38]; EDM [39]; as well as surface coating and repair [40].

Similar drivers refer to machines. Different factors are in use to quantify the utilization of machines, typically in terms of availability, performance and quality. In this context, the most common operational indicator in use is the overall equipment effectiveness (OEE), which measures different types of production losses and indicates areas of technology and operations improvement [41]. The improvement of OEE is not as much a technological issue as it is organizational; training of machine operators and adequate maintenance can both contribute to high OEE. Additional key indicators refer to capability indexes, quantifying the ability of a machine 
(Cmk) and/or a process (Cpk) to meet the specified property requirements. Basic concepts and methods of capability are standardized (ISO 21747). Capability indicators are technological in nature. Their improvement can be, for example, achieved by implementing advanced technologies and automation that increase productivity and require fewer but more skilled workers: ICT, sensors, robotics are typical drivers of improved capability.

\section{Proposed framework for "smart tool, machine, and special equipment"}

This section briefly describes the basic structure of the framework. Currently, a key set of ideas in the framework includes organizational and technology related attributes.

The basic premise of the "smart tool, machine and special equipment" framework is, that it is possible to create added value for the customer using modern organizational and technological approaches. With the use of product life cycle management we can create added value in the eyes of the customer. We can realize the added value with the use of modern organizational (virtual organization, technology networks, new business models, etc.) and technological approaches (ICT, sensors, new materials, etc.).

The starting points for developing this framework are, among others, strategic guidelines of the European technology platform "Manufuture". Fig. 3 is based on these guidelines and predicts four possible strategies for implementation in the factory of the future. As it was argued in the preceding sections, the key goal for the future tool/machine/special equipment factory is the creation of added value. When we discuss EU tool/machine/special equipment manufacturers, as a representative of knowledge based organization, two of the proposed strategies are applicable, as depicted in Fig. 3:

- Technological excellence (leader in the field), or

- New business models and technologies for strategic innovation

\section{CONCEPT OF}

\section{"SMART TOOL, MACHINE} SPECIAL EQUIPMENT «

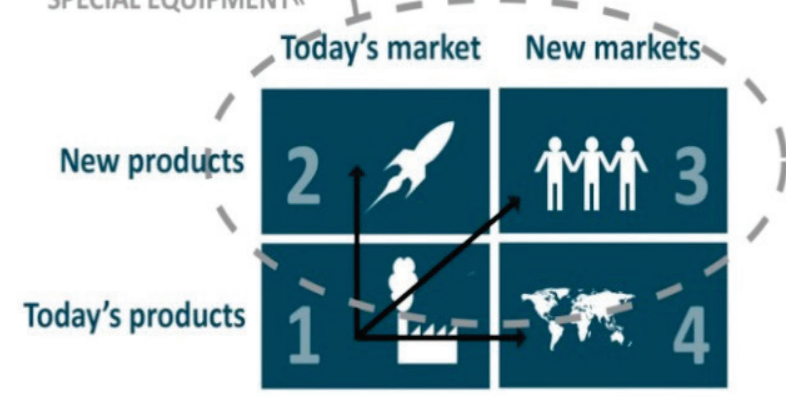

$$
\begin{aligned}
& \begin{array}{l}
\text { Centralized local } \\
\text { production }
\end{array} \\
& 2 \begin{array}{l}
\text { New business models } \\
\text { and technologies for } \\
\text { strategic innovations }
\end{array} \\
& \text { Tehnological excelence } \\
& \text { (leader in the field) }
\end{aligned}
$$

Figure 3 Strategies for implementation in the factory of the future [2]
Industry-specific examples of attributes relevant to the framework of the smart tool, machine and special equipment are either organization (Tab. 1) or technologyrelated (Tab. 2). In this context, manufacturers of tools need a framework in which they can evaluate and track the performance of their operational attributes.

Table 1 Organization-related attributes

\begin{tabular}{|c|l|}
\hline & $\begin{array}{l}\text { Organization-related attributes of "smart tool, machine, } \\
\text { and special equipment" }\end{array}$ \\
\hline 1. & $\begin{array}{l}\text { Taking a greater responsibility for the product through its } \\
\text { entire life cycle. }\end{array}$ \\
\hline 2. & $\begin{array}{l}\text { In the extreme case, a complete shift of ownership from } \\
\text { customer to producer. }\end{array}$ \\
\hline 3. & New "smart" customer relationship management system. \\
\hline 4. & $\begin{array}{l}\text { The management of the tool/machine/equipment } \\
\text { corresponds to the "Life Cycle management" framework. }\end{array}$ \\
\hline 5. & $\begin{array}{l}\text { Implementation of an open innovation platform for the } \\
\text { development and the operation of the } \\
\text { tool/machine/equipment that involves the cooperation of } \\
\text { all business partners and stakeholders. }\end{array}$ \\
\hline 6. & $\begin{array}{l}\text { New forms of cooperation - virtual capacity database, } \\
\text { technology networks, virtual organizations, etc. }\end{array}$ \\
\hline
\end{tabular}

Table 2 Technology-related attributes

\begin{tabular}{|c|l|}
\hline & $\begin{array}{l}\text { Technology-related attributes of "smart tool, machine, and } \\
\text { special equipment" }\end{array}$ \\
\hline 1. & $\begin{array}{l}\text { The use of advanced materials that lower the need for } \\
\text { maintenance. }\end{array}$ \\
\hline 2. & $\begin{array}{l}\text { Modular approach in tool/machine/equipment } \\
\text { development, shorter design, production and maintenance. } \\
\text { More flexibility. }\end{array}$ \\
\hline 3. & $\begin{array}{l}\text { A system of sensors that allow tool/machine/equipment } \\
\text { monitoring at a distance. }\end{array}$ \\
\hline 4. & A system for tool management at a distance. \\
\hline 5. & $\begin{array}{l}\text { A virtual e-tech production platform that connects } \\
\text { partners within a holistic production network. }\end{array}$ \\
\hline
\end{tabular}

These attributes were formed as the result of reviewing the state-of-the-art, benchmarking industrial realms of the respected fields, as well as our own critical thinking. They represent the framework and serve as guidelines for the development of the smart product and accompanying business model. The use of such attributes presents two major challenges. Firstly, manufacturers need a structured approach to gauge their progress on attributes and to further identify opportunity areas. Secondly, performance analysis requires the development of formal models, which requires expertise and a substantial development effort and is beyond the scope of this work. Nevertheless, the advancement of manufacturing performance is expected by implementing any of the identified organization-related attributes (Table $1)$. On the other hand, new technological ideas in the framework are to enable continuous improvement for advancing technology at the factory level, for which a set of relevant attributes are identified (Tab. 2).

Companies need to rethink the fundamental ways in which they generate ideas and bring them to the market, as stated by Chesbrough [42], who introduced the model of open innovation. Chesbrough's model shows us how to accelerate organizational innovation processes by promoting and supporting flow and commercialization of the internal as well as external ideas with related innovations. Published research regarding innovation in 
Slovene manufacturing companies and the feasibility of open innovation has shown a favourable correlation between the financial inputs related to open innovation and innovation performance of the companies [43].

These characteristics in Tables 1 and 2 provide many new possibilities for the toolmakers and their customers. The toolmaker in this model does not sell only the tool/product itself, but rather a solution for the customer's manufacturing process, based on his knowledge and know how. In this way, the concept tries to apply the proposition of Product-Service Systems [44] to the tool making sector. The tool can be better monitored from a distance and better additional service and maintenance can be provided if needed. Furthermore, the change of ownership is not necessary the tool itself can be leased. To develop such a product, a holistic overview and knowledge from different fields of expertise are required. We propose the use of a modular approach to development, application of sensors and a platform for better tool monitoring from a distance, as well as a different organizational structure amongst others.

\section{Research results}

\subsection{Guidelines for framework application}

The framework presented combines a wide range of interdisciplinary issues and proposes some new ideas and hypotheses, such as growing trends across the industry, new buyers' priorities and perceived added value of the smart framework itself. The research dealing with broader framework validation in the eyes of the buyers and producers, as well as testing of the basic premises of the framework, has already been published in JBSMSE [45]. For the purpose of this manuscript, the focus was on the technological possibilities for creating added value through sales services, therefore, the more technical aspect of the research is presented - the guidelines dealing with the technological parameters and production information needed for on-line control.

The starting point for this part of the research is the assumption of the "smart tool, machine, and special equipment" framework, that the producer would provide added value in the form of after sales services and responsibility for the product during the entire life cycle. Taking on such a business model is risky for the producer, therefore, the process must not be based solely on the competencies, the good will and honesty of the buyer, but rather on real data gathered during production, that is the operation of the respected tool, machine or special equipment. Today this is more possible than ever, with the use of modern ICT. Smaller autonomous sensors for various applications are becoming available on the market, as well as the possibility of wireless communication and data transfer within the production facilities and between companies. It is possible and it is already happening in manufacturing industries, for example:

- Automotive industry (communication vehicle service, trend of constant vehicle connectivity to various networks),

- Electrical engineering industry (smart factory of General Electric in New York),

- Telecommunication (smart phones),
- Cloud based software and operating systems,

- Etc.

The technology exists, but before we can start developing solutions for a specific product, we have to know, which parameters we need to control. This was the focus of the presented research. Various producers were asked to assign grades to the parameters for their type of product, according to their importance for on-line monitoring from a distance. The parameters offered were based on expert literature and divided according to different products, as presented. An open question was added, providing the possibility of entering additional parameters/information of importance. The aim was to get the opinion directly from the producers with many years of practical experience.

\subsection{Industry survey}

An industry survey was made by the use of an anonymous questionnaire. The target population was relatively small, since it consisted of Slovene producers of custom made tools and selected producers of machines and equipment. Target population consists of only 50 companies. That is why we decided to study the entire population. The problem is that the questionnaire was answered on a volunteer basis. The sample is therefore partly biased.

The questionnaire was distributed to Slovene manufacturers of custom made tools, machines and equipment, chosen as appropriate for the purpose of this research. The population was chosen on the basis of the registry of the Slovene Chamber of Commerce (GZS). All manufacturers of custom tools for industrial application were included, along with the majority custom made machines and equipment manufacturers. Some of them were ruled out as inappropriate, e.g. manufacturers of small standard parts, as well as small craftsmen and metal workshops. This enabled us to get a more focused target population of 50 organizations, which are most relevant for this research.

Data collection was comprised of multiple phases of email and phone communication. The survey was assisted by the Toolmakers Cluster of Slovenia (TCS) and we got in direct contact with all the companies and the respected individuals, which were responsible and competent to answer the questionnaire. In the end, the response rate was 21 companies, which represents $42 \%$ of the population.

\subsection{Results}

The parameters are divided according to the specific products; that is: sheet metal forming tools, injection moulding tools, die casting tools, other tools, and custom made machines and devices. The producers labelled the parameters according to their importance on a Likert scale, ranging from 1 - not important to 5 - very important. The resulting average grades are presented graphically in Figs. 4, 5, 6, 7, and 8. This information constitutes the library of technological parameters and information. 


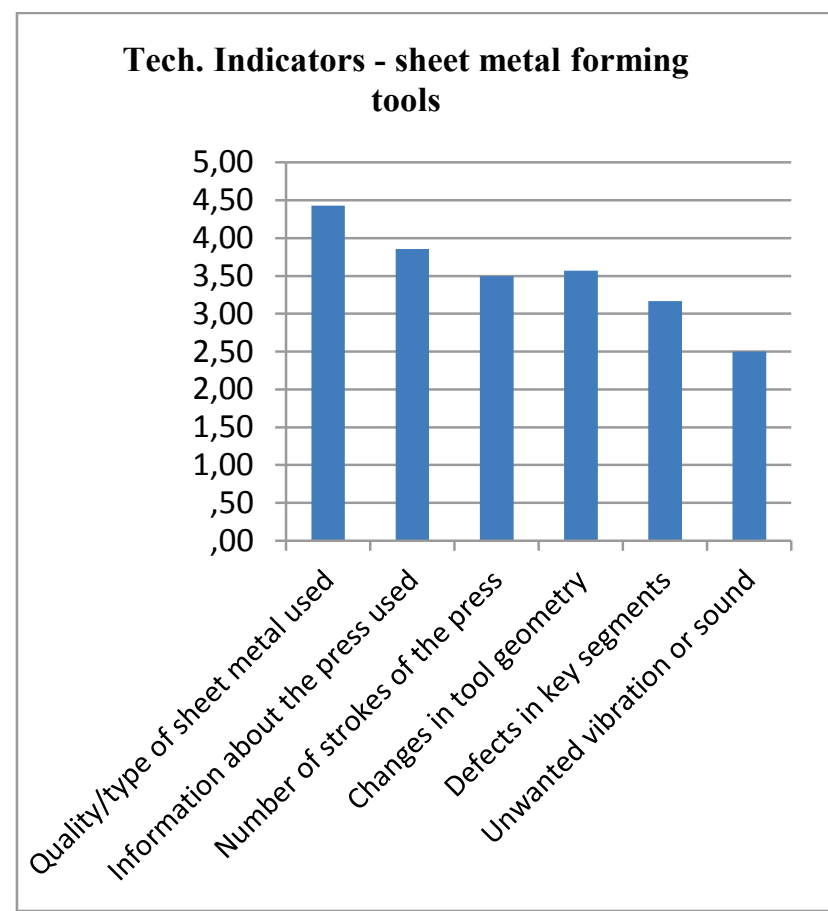

Figure 4 Diagram of technological indicators for sheet metal forming tools

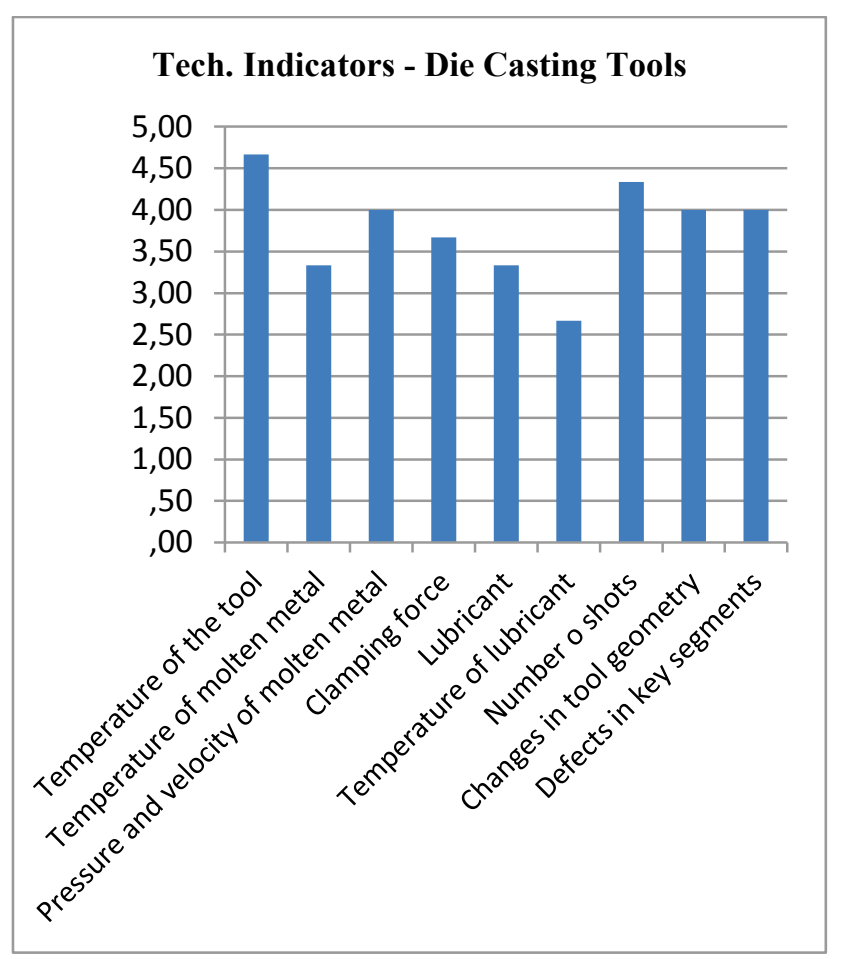

Figure 5 Diagram of technological indicators for die casting tools

In the open section, titled "other important indicators", the producers added the following:

Sheet metal forming tools:

- Cpk, extent of servicing, tools weakest segment

- Use of appropriate material, heat treatment and geometry/tolerance

Injection moulding tools: no additional comments.

Die casting tools:

- Stability of flow, especially in the 3 stage process
Tech. Indicators - Injection Molding Tools

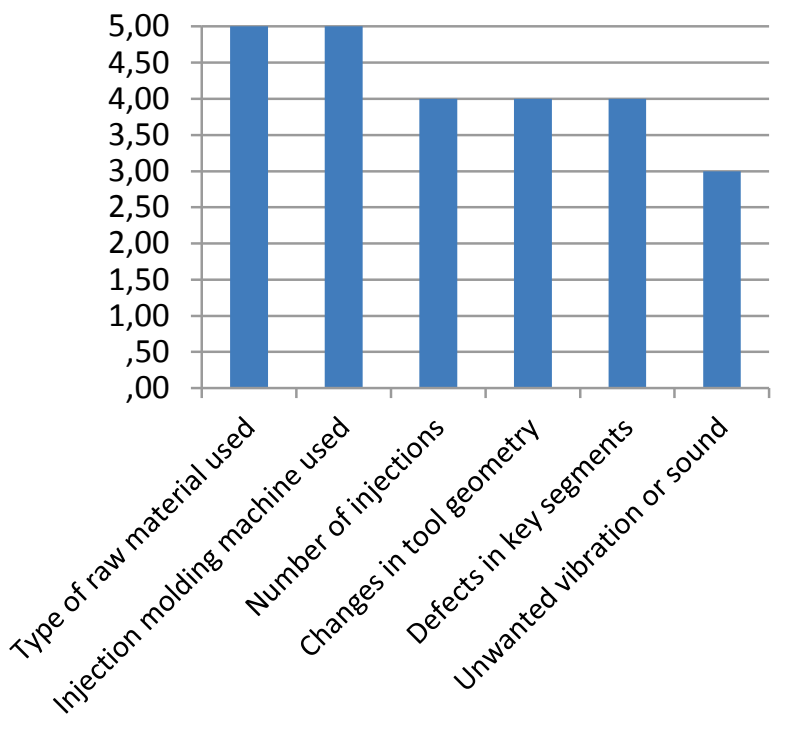

Figure 6 Diagram of technological indicators for injection moulding tools

Tech. Indicators - Other Tools

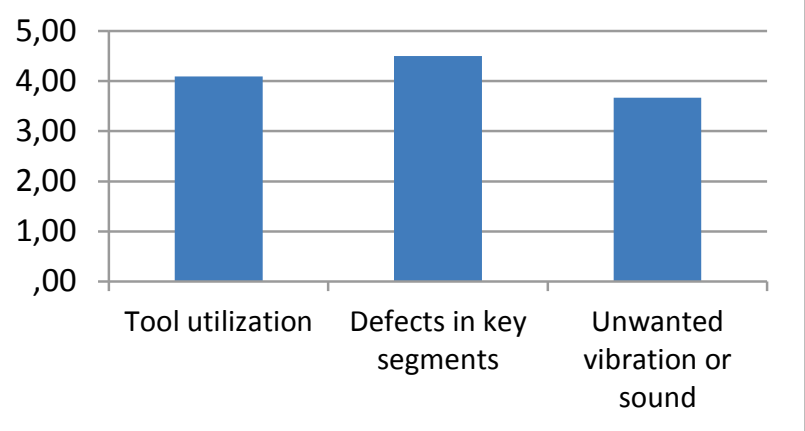

Figure 7 Diagram of technological indicators for other tools

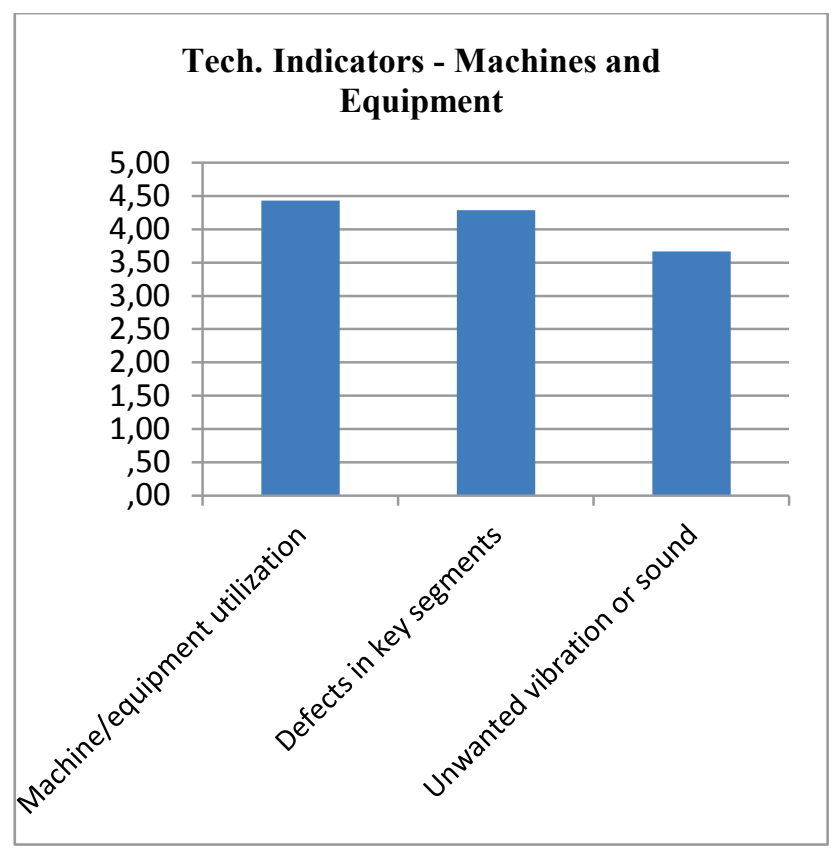

Figure 8 Diagram of technological indicators for machines and equipment 
Other tools:

- Cpk, satisfaction of operators in handling and exchange

- Stability of controller function

- Users' feedback and proposal for improvement

- Tool wear

- Number of machine setups.

Machines and equipment:

- $\quad$ Set targets for OEE.

\section{Conclusions}

The background of the "Smart tool, machine, and special equipment" framework consists of a broad interdisciplinary overview of research, case studies and best practices related to: modern organizational forms and collaboration, studies and forecasts for the automotive industry, life cycle management, sustainability and the demands of a modern business environment. Basic EU guidelines contained in the European platform Manufuture - Factories of the Future, were also taken into account. The findings are adapted for the use in tool making and building of special machines and equipment for industrial customers.

With the intent to create added value, as a prerequisite for survival and/or success of the tool factory in the competitive global environment, the factory must be aligned with modern industry trends, which have a direct or indirect influence, as well as with novel business approaches enabled by modern forms of organization and ICT, such as networks, virtual organizations, collaboration platforms, etc. These have to be considered and implemented as necessary in the development of the respective product and/or accompanying services and can as such have a profound influence on the business model of a company. The goal is creating added value for the customer and a competitive advantage for the company with it.

The attributes of the framework presented in this article were further investigated for their practical feasibility, using two separate surveys, one targeting customers and the other producers of industrial tools, machines and equipment across Europe. In this manuscript some of the important state of the art findings are presented, the framework itself is briefly laid out and a part of the research results are exclusively presented.

A library of technological indicators regarding online monitoring of the state of the specified tool or custom machine/special equipment during its operation was identified. Through survey research the relative importance of these indicators was tested. The manufacturers of respective products were asked to assign grades of importance according to the Likert scale to the indicators, which they feel are most needed for on-line monitoring of their products utilized at a remote location. This monitoring process would provide a base for the management of the product through its entire life cycle, providing support and after sales service to the buyer.

We see that the actual state of the tool itself is important, interestingly, other inputs of the production process are deemed even more important. For example, in the sheet metal forming tools, the type and quality of the sheet metal used and the type of press used are regarded more important indicators for tool performance/ malfunction than the tool geometry and tool defects themselves. The results are the same for the injection moulding tools. The two most important indicators $(5 / 5$ on the Likert scale) are the type of material and the type of injection moulding machine used. Monitoring tool utilization is also regarded very important, and in the case of custom made machines and special equipment as the most important factor. Unwanted vibrations of sounds were also considered as possible indicators that could be measured on site of utilization, but were regarded as the least useful indicators, although still important (3-4/5 Likert).

Some additional indicators were proposed by the manufacturers of sheet metal forming tools, which could also be used for other tools, such as the extent of the servicing of the tool and the monitoring of a specific tools weakest segment. Manufacturers of these custom products would also value feedback of the user experience, such as operator satisfaction and user's proposals for improvement. This type of feedback and information exchange is one of the important characteristics of value creation within the proposed framework.

These findings serve as a starting point for creating a smart product, providing added value in the form of after sales services and the responsibility for the product during the entire life cycle. The smart product manufacturer can use the library as well as the proposed framework and its attributes as a blueprint in the research and development of its specific smart product and the possible changes in the accompanying business model.

\section{Acknowledgements}

The research presented was partly financed by the European Union, European Social Fund.

\section{References}

[1] Semolič B. Development of marketing and strategic business collaboration of toolmakers in Slovenia, Celje, Tool Cluster Slovenia - TCS. 2008.

[2] European Commission. MANUFUTURE - a vision for 2020, assuring the future of manufacturing in Europe. Luxembourg. Office for Official Publications of the European Communities. 2004.

[3] Kagermann, H.; Wahlster, W.; Helbig, J. Implementation of recommendations for the future project Industrie 4.0. German Federal Ministry of Education and Research, 2013. URL:http://www.bmbf.de/pubRD/Umsetzungsempfehlung en Industrie4 0.pdf

[4] Kalmbach, R.; Wolfgang, B.; Kleimann, P. G.; Hoffmann, M. Automotive landscape 2025 - opportunities and challenges ahead. Roland Berger Strategy Consultants. 2011.

[5] Tepeš, M. Virtual Organization and Virtual Capacities Database: Case study of Slovene toolmaking sector and Slovene plastics sector. Ljubljana. Faculty of Economics. 2010.

[6] Afsarmanesh, H.; Camarinha-Matos, L. M. A Framework for Management of Virtual Organization Breeding Environments. // IFIP International Federation for Information Processing, 186, (2005). Boston: Springer. 
[7] Web page of European Product Development Enterprises in Manufacturing and Innovation, URL: www.emiracle.eu/

[8] Web page of Tools cluster of Slovenia. URL: www.toolscluster.net

[9] Web page of International Virtual Laboratory for Enterprise Interoperability. URL: http://interop-vlab.eu/

[10] Bischoff, R.; Bueno, R.; Caldeira, J. C.; Chryssolouris, G.; Decubber, C.; Pinte, J.; Dunkerton, S.; Flaig, K.; Wilkens, M.; Hanisch, C.; Goericke, D.; Knecht, F.; Mattucci, M.; Meiners, E.; Pegman, G.; Richet, D.; Carton, M.; Tolio, T. Factories of the Future PPP Strategic Multi-annual Roadmap. http://www.manufuture.org/manufacturing/wpcontent/uploads/FoF_PPP_Roadmap_Final_Version.pdf (April, 2010).

[11] Swamidass, P. M. Innovations in Competitive Manufacturing. New York: Amacom. 2002.

[12] Chandna, R. Measurement of Agility in Manufacturing Systems: A Fuzzy Logic Approach. // Proceedings of II. World Congress on engineering. London, 2008.

[13] Goldman, S. L.; Nagel, R. N.; Preiss, K. Agile Competitors and Virtual Organizations. New York: Van Nostrand Reinhold. 1995.

[14] Hamel, G.; Prahalad, C. K. Competing for the future Boston: Harward Business School Press. 1994.

[15] Hausner, U.; Teichmann, K.; Albers, S.; Hussla, I. Management of Virtual Enterprises: Results from Case Studies in Northern Germany. Proceedings of IX. International Conference of Concurrent Enterprising, Espoo: ICCE. 2003.

[16] Katzy, B.; Chunyan, Z.; Herman, L. Reference Models for Virtual Organizations. // Virtual Organizations: Systems and Practices (2004), pp. 45-58. Boston: Springer.

[17] Pang, L. Understanding Virtual Organizations. // Information Systems Control Journal 6 (2001). http://www.isaca.org/Template.cfm?Section=Home\&CON TENTID $=17425 \&$ TEMPLATE $=/$ ContentManagement/Con tentDisplay.cfm (March, 2010).

[18] Cartwright, J.; Friedman, J.; Goldstein, B.; Minchella, J. (n.d.). Virtual factory project tackles integration of supply chain systems. http://thor.inemi.org/webdownload/ newsroom/Articles/FEMSI0299.pdf (February, 2010).

[19] Sluga A.; Butala P.; Peklenik J. A conceptual Framework for Collaborative Design and Operations of Manufacturing Work Systems. // CIRP Annals - Manufacturing Technology. 54, 1(2005), pp. 437-440. DOI: 10.1016/S00078506(07)60139-5

[20] Butala P.; Sluga A. Autonomous Work Systems in Manufacturing Networks. // CIRP Annals - Manufacturing Technology, 55, 1 (2006), pp. 521-524. DOI: 10.1016/S00078506(07)60473-9

[21] Umeda Y.; Takata S.; Kimura F.; Tomiyama T.; Sutherland J. W.; Kara S.; Herrmann C.; Duflou J. R. Toward integrated product and process life cycle planning - A environmental perspective. // CIRP Annals Manufacturing Technology. 61, 2 (2012), pp. 681-702. DOI: 10.1016/j.cirp.2012.05.004

[22] Westkaemper, E.; Alting, A. Life Cycle Management and Assessment: Approaches and Visions towards Sustainable Manufacturing. // CIRP Annals of Manufacturing Technology. 49, 2(2000), pp 501-526. DOI: 10.1016/S00078506(07)63453-2

[23] Rashid A.; Asif F. M. A.; Krajnik P.; Nicolescu C. M. Resource Conservative Manufacturing: an essential change in business and technology paradigm for sustainable manufacturing. // Journal of Cleaner Production. 54, 15 (2013), pp. 166-177. DOI: 10.1016/j.jclepro.2013.06.012

[24] Tepeš, M.; Semolič, B.; Krajnik, P.; Kopač, J. Tool making Factory of the Future - innovative business models and the concept of intelligent e-tools. // The Journal of $11^{\text {th }}$ International Conference in Management of Innovative
Technologies \& $2^{\text {nd }}$ International Conference on Sustainable Life in Manufacturing, Fiesa, Slovenia. 2011.

[25] Mitchell, M.; Tseng; Jiao, J.; Merchant, M. E. Design for Mass Customization. // CIRP Annals - Manufacturing Technology, 45, 1(1996), pp. 153-156. DOI: 10.1016/S00078506(07)63036-4

[26] Jiao, J.; Ma, Q.; Mitchell, M.; Tseng. Towards high valueadded products and services: mass customization and beyond. // Technovation. 23, 10(2003), pp. 809-821. DOI: 10.1016/S0166-4972(02)00023-8

[27] Pusavec F.; Krajnik P; Kopac J. Transitioning to sustainable production - Part I: application on machining technologies. // Journal of Cleaner Production, 18, 2 (2010), pp. 174-184. DOI: 10.1016/j.jclepro.2009.08.010

[28] Pusavec, F.; Kramar, D.; Krajnik, P; Kopac, J. Transitioning to sustainable production - Part II: evaluation of sustainable machining technologies. // Journal of Cleaner Production. 18, 12(2010), pp. 1211-1221. DOl: 10.1016/j.jclepro.2010.01.015

[29] Herrmann, C.; Thiede, S.; Kara, S.; Hesselbach, J. Energy oriented simulation of manufacturing systems - Concept and application. // CIRP Annals - Manufacturing Technology. 60, 1(2011), pp. 45-48. DOI: 10.1016/j.cirp.2011.03.127

[30] Seuring, S.; Mueller, M. From a literature review to a conceptual framework for sustainable supply chain management. // Journal of Cleaner Production. 16, 15(2008), pp. 1699-1710. DOI: 10.1016/j.jclepro.2008.04.020

[31] Koplin, J.; Seuring, S.; Mesterharm, M. Incorporating sustainability into supply management in the automotive industry - the case of the Volkswagen AG. // Journal of Cleaner Production. 15, 11-12(2007), pp. 1053-1062.

[32] McWilliams, A.; Siegel, D. Corporate Social Responsibility: a Theory of the Firm Perspective. // Academy of Management Review. 26, 1(2001), pp. 117127.

[33] Altan, T.; Lilly, B.; Yen, Y. C. Manufacturing of Dies and Molds. // CIRP Annals - Manufacturing Technology. 50, 2(2001), pp. 404-422. DOI: 10.1016/S0007-8506(07)62988-6

[34] Merklein, M.; Allwood, J. M.; Behrens, B. A.; Brosius, A.; Hagenah, H.; Kuzman, K.; Mori, K.; Tekkaya, A. E.; Weckenmann A. Bulk forming of sheet metal. // CIRP Annals - Manufacturing Technology. 61, 2(2012, pp. 725745. DOI: 10.1016/j.cirp.2012.05.007

[35] Muhič, M.; Tušek, J.; Kosel, F.; Klobčar, D. Analysis of Die Casting Tool Material. // Journal of Mechanical Engineering. 56, 6(2010), pp. 351-356.

[36] Krajnik, P.; Drazumeric, R.; Badger, J. Optimization of peripheral non-round cylindrical grinding via an adaptable constant-temperature process. // CIRP Annals Manufacturing Technology. 62, 1(2013), pp. 347-350. DOI: 10.1016/j.cirp.2013.03.012

[37] Krajnik, P.; Kopač, J. Modern machining of die and mold tools. // Journal of Materials Processing Technology. 157158, 20(2004), pp. 543-552. DOI: 10.1016/j.jmatprotec.2004.07.146

[38] Mijuškovič, G.; Krajnik, P.; Kopač, J. Improvement of positional accuracy of precision micro milling center using pitch error compensation. // Tehnicki vjesnik-Technical Gazette. 20, 4(2013), pp. 629-634.

[39] Valentinčič, J.; Brissaud, D.; Junkar, M. EDM process adaptation system in toolmaking industry. // Journal of Materials Processing Technology. 172, 2(2006), pp. 291298. DOI: 10.1016/j.jmatprotec.2005.10.019

[40] Klobčar, D.; Tušek, J.; Taljat, B.; Kosec, L.; Muhič, M. Suitability of maraging steel weld cladding for repair of die casting tooling. // International Journal of Materials research. 99, 9(2008), pp. 1006-1014. DOl: $10.3139 / 146.101733$ 
[41] Muchiri, P.; Pintelon, L.; Performance measurement using overall equipment effectiveness (OEE): literature review and practical application discussion. // International Journal of Production Research. 46, 13(2008), pp. 3517-3535. DOI: 10.1080/00207540601142645

[42] Chesbrough, H.; Vanhaverbeke, W.; West, J.; Open Innovation: Researching a New Paradigm. Oxford University Press. (2008).

[43] Fatur, P.; Likar, B.; Ropret, M.; Going open while innovating: does it pay? // International journal of industrial engineering and management. 1, 3(2010), pp. 77-83.

[44] Mont, O. K. Clarifying the concept of product-service systems. // Journal of Cleaner Production. 10, (2002), pp. 237-245. DOI: 10.1016/S0959-6526(01)00039-7

[45] Tepeš, M.; Krajnik, P.; Kopač, J.; Semolič, B.; Smart tool, machine and special equipment: Overview of the concept and application for the Tool Making Factory of the Future. // Journal of the Brazilian Society of Mechanical Sciences and Engineering. (2014), DOI: 10.1007/s40430-014-0229-9

\section{Authors' addresses}

\section{Matic Tepěs, MSc}

Faculty of Mechanical Engineering

Askerceva ulica 6

SI-1000, Ljubljana, Slovenia

E-mail: matic.tepes@gmail.com

\section{Peter Krajnik, PhD, Assistant Professor}

Chair of Machining Technology Management

Faculty of Mechanical Engineering

Askerceva ulica 6

SI-1000, Ljubljana, Slovenia

E-mail: peter.krajnik@fs.uni-lj.si

\section{Janez Kopač, PhD, Professor}

Department of Machining Technology Management

Laboratory for cutting - LABOD

Faculty of Mechanical Engineering

Askerceva ulica 6

SI-1000, Ljubljana, Slovenia

E-mail: janez.kopac@fs.uni-lj.si 